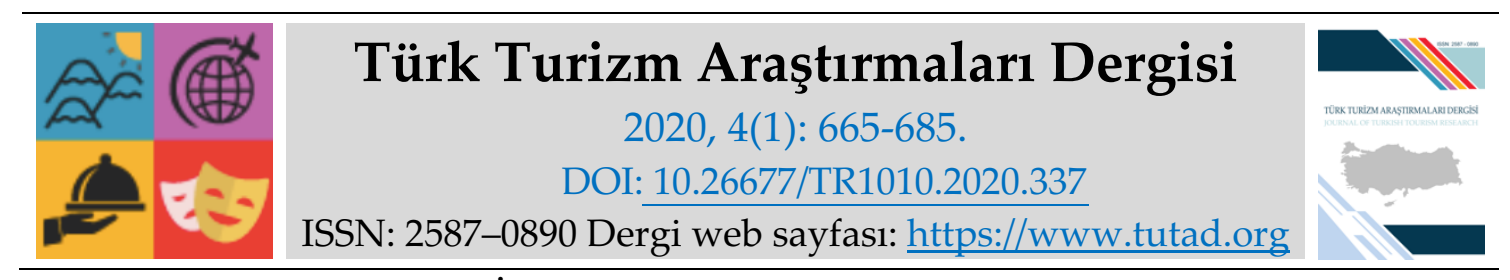

ARAŞTIRMA MAKALESI

\title{
Ayurveda Beslenme Sistemine Uygun Türk Mutfağı Örnek Menü Planlaması
}

Öğr. Gör. Dilek ÇíFTCİ, Mehmet Ali Aydınlar Acıbadem Üniversitesi, Meslek Yüksekokulu, İstanbul, e-posta: dc.dilekciftci@gmail.com

ORCID: https://orcid.org/0000-0002-2773-8676

Öğr. Gör. Elif DORMAN, Mehmet Ali Aydınlar Acıbadem Üniversitesi, Meslek Yüksekokulu, İstanbul, e-posta: elifdorman@yahoo.com

ORCID: https://orcid.org/0000-0001-9718-2100

Dr. Öğr. Üyesi Özgür KIZILDEMİ, İstanbul Gelişim Üniversitesi, Uygulamalı Bilimler Yüksek Okulu, e-posta: o.kizildemir@gmail.com

ORCID: https://orcid.org/0000-0003-4040-4547

Öz

Ayurveda dünyanın en eski bütünsel sağlık ve beslenme sistemlerinden birisidir. Dünyada sağlıklı beslenme trendlerinin artmasıyla birlikte, ayurveda özellikle batıda, her geçen gün üzerine çalışmaların arttığı bir konu olarak karşımıza çıkmaktadır. Ayurveda felsefesinde insanın doğuştan sahip olduğu özelliklere ve mevsimlere göre beslenmek, dış dünya ile insanın iç dünyasının birbiriyle uyumlu ve bedeninin sağlıklı olması önemlidir. Günümüzde sağlıklı yaşam için yaygın olarak uygulanan ayurveda beslenme sistemine göre restoran menülerinde ayurvedik yiyecek ve içeceklerin bulunmamasından dolayı bu çalışmaya ihtiyaç olduğu düşünülmüştür. Bununla birlikte dünya çapında kabul görmüş ayurveda beslenme sistemi vasitasıyla Türk yemeklerinin evrensel olarak tanınmasına katkı sağlanması hedeflenmiştir. Bu çalışmada, ayurveda beslenme sisteminin Türk mutfağı yemeklerine uyarlanması amaçlanmıştır. Özellikle tüketilmesi yaygın ve sevilen geleneksel Türk yemekleri dikkate alınıp, ayurveda yemek yeme sistemine göre yemek uyarlamaları yapılarak menüler düzenlenmiştir. Her üç dosha için tüketilmesi uygun olan yemekler özgün reçeteler kullanılarak gastronomi laboratuvarında pişirilmiş ve resimleri çekilmiştir. Günümüz klasik menüsü dikkate alınarak çorba, soğuk başlangıç, sıcak başlangıç, ana yemek ve tatlıdan oluşan menüler planlanmıştır. Bununla birlikte vata, pitta, kapha doshalarının her biri için beş öğeli menüler hazırlanmış olup, toplam 15 yemek tarifi oluşturulmuştur. Çalışmada yer alan yemek tarifleri Türk mutfak kültüründe bilinen, sevilen, klasik ve yöresel yemeklerin, doshaların özel beslenme kuralları göz önünde bulundurularak yeniden uyarlanması ile hazırlanmıştır. Bu uygulamalı çalışmanın sonucunda, Türk mutfak kültüründe var olan ürünlerle hazırlanan menülerin ayurvedaya uyarlanabilir ve uygun olduğu görülmüştür. Ayurvedik menülerin Türk mutfak kültürüne uygun bir şekilde çeşitlendirilmesinin ve içeriklerinin zenginleştirilmesinin mümkün olduğu saptanmış ve ayurvedik yiyeceklerin Türk mutfağına uyarlanmış haliyle yiyecek içecek sektörünün menülerinde bulunabileceği önerisi getirilmiştir.

Anahtar Kelimeler: Ayurveda, Türk Mutfağı, Menü.

Makale Gönderme Tarihi: 18.11.2019

Makale Kabul Tarihi: 19.01.2020

Önerilen Attf:

Çiftci, D., Dorman, E. ve Kızıldemir, Ö. (2020). Ayurveda Beslenme Sistemine Uygun Türk Mutfağı Örnek Menü Planlaması, Türk Turizm Araştırmaları Dergisi, 4(1): 665-685.

(C) 2020 Türk Turizm Araştırmaları Dergisi. 


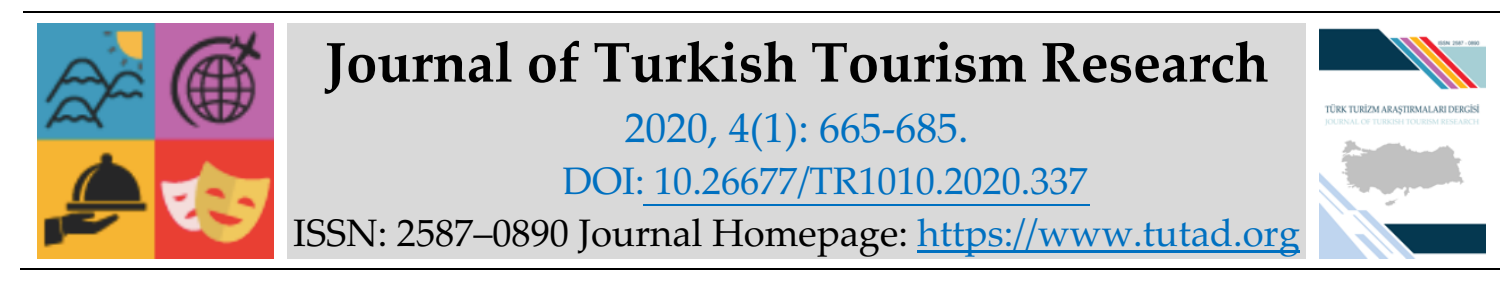

RESEARCH PAPER

\title{
Sample Menu Planning of Turkish Cuisine According to Ayurvedic Nutrition System
}

Lecturer Dilek ÇíFTĊ, Mehmet Ali Aydinlar Acibadem University, Vocational School of Higher Education, İstanbul, e-mail: dc.dilekciftci@gmail.com

ORCID: https://orcid.org/0000-0002-2773-8676

Lecturer Elif DORMAN, Mehmet Ali Aydinlar Acibadem University, Vocational School of Higher Education, İstanbul, e-mail: elifdorman@yahoo.com

ORCID: https://orcid.org/0000-0001-9718-2100

Assistant Prof. Dr. Özgür KIZILDEMIR, Istanbul Gelişim University, School of Applied Sciences, İstanbul, e-mail: o.kizildemir@gmail.com

ORCID: https://orcid.org/0000-0003-4040-4547

\begin{abstract}
Ayurveda is one of the world's oldest holistic health and nutrition systems. With the increasing trend of healthy eating in the world, ayurveda, especially in the West, becoming an issue where studies are increasing day by day. According to ayurveda philosophy, it is important to be fed according to the natural features and seasons of the human being, in terms of the harmony between the external world and the inner world of the human being and the health of the body. This study was thought to be needed due to the lack of ayurvedic food and beverages in the restaurant menus, which are compatible with the ayurvedic nutritional system commonly used for healthy living in today's world. In addition, it is aimed to contribute to the universal recognition of Turkish food through the worldwide accepted ayurvedic nutrition system. In this study, it is aimed to adapt Ayurvedic nutrition system to Turkish cuisine. Especially the traditional Turkish foods that are widely consumed and loved are taken into consideration and menus are arranged by making food adaptations according to the ayurvedic eating system. Foods suitable for consumption for all three doshas were cooked and photographed in the gastronomy laboratory using original recipes. Taking into consideration today's classic menu, menus consisting of soup, cold start, hot start, main course and dessert are planned. In addition, five-item menus were prepared for each of the vata, pitta, kapha doshas, and a total of 15 recipes were created. The recipes included in the study were prepared by re-adapting the classic and local dishes, which are known in the Turkish cuisine culture, to the special dietary rules of doshas. The menus prepared with the products available in the Turkish cuisine culture were found to be adaptable and appropriate to ayurveda. It has been determined that it is possible to diversify and enrich the ayurvedic menus in accordance with the Turkish cuisine culture and suggest that ayurvedic foods can be found in the menus of the food and beverage sector as adapted to Turkish Cuisine.
\end{abstract}

Keywords: Ayurveda, Turkish Cuisine, Menu.

Received: 18.11.2019

Accepted: 19.01 .2020

Suggested Citation:

Çiftci, D., Dorman, E. and Kızıldemir, Ö. (2020). Sample Menu Planning of Turkish Cuisine According to Ayurvedic Nutrition System, Journal of Turkish Tourism Research, 4(1): 665-685.

(C) 2020 Türk Turizm Araştırmaları Dergisi. 


\section{GİRIŞ}

Yiyecek içecek sektörü, dünyada ve Türkiye'de en hızlı büyüyen sektörlerden birisidir. İnsanların iş yaşamında çok fazla vakit geçirmelerinden ve evde yemek pişirmeye zaman ayıramama gibi etkenlerden dolayı talebin artmasıyla yiyecek içecek sektörünün hızla ilerlediği görülmektedir. Bununla birlikte daha hızlı ve hazır gıdaların tüketiminden dolayı birçok sağlık problemlerinin ortaya çımasıyla birlikte sağlıksız beslenme, obezite ve diğer sağlık sorunları salgınına önemle dikkat çekilmektedir (Jones, 2009). Günümüzde dışarıda yiyip içmenin yaygınlaşması ve sağlık sorunlarının artmasıyla sağlıklı yeme içme talebi, sağlık bilincinin bir türevi haline gelmektedir (Çakıcı ve Yıldız, 2017).

Günümüzde bilinçli yiyecek tüketim tercihlerinin restoranlarda daha sağlıklı menülerin hazırlanmasına neden olduğu bilinmektedir. Farkındalık, ihtiyaç ve yaşam tarzı faktörleri, sağlıklı yiyecek ve içecek seçenekleri için bir talep yaratmıştır. Sağlıklı beslenme eğilimi, artan harcanabilir gelirler ve küreselleşme nedeniyle ivme kazanmıştır. Gıda tercihlerinin ve yaşam tarzının hastalıklar ile ilişkisi hakkında müşteriler arasında artan bir bilinç söz konusudur (Kraft ve Goodell, 1993). Birçok müşterinin sağlıklı ve uzun bir yaşamı destekleyen gidaları tercih ettiği görülmektedir. (Chen, 2011). Bu da yeni beslenme akımlarının ortaya çıkmasına sebep olmaktadır. İnsanların sağlıklarının bozulmasının eski çağlardaki beslenme şekline geri dönüşün nedeni olduğu hatta bir trend haline geldiği gözlenmektedir (Jindabot, 2015). Çağlar öncesinden bilinen en eski sağlıklı beslenme sistemine sahip olan ayurveda insanların sağlıklı bir yaşam sürmesi felsefesi üzerine kurulu bir tıp ve beslenme sistemi olarak ortaya çıkmaktadır.

Dünya Sağlık Örgütü tarafından da bilinen en eski tıp sistemi olarak kabul edilen ayurveda da bireyleri belirli özelliklerine göre sınıflandırarak bu çerçevede beslenmenin ve yaşamın, bedensel ve ruhsal açıdan dengeli ve mutlu bireyler oluşturulacağı vurgulanmaktadır. Batıda, özellikle A.B.D'de oldukça ilgi ve kabul gören ayurvedanın, kendine özgü beslenme sistemiyle yine bahsi geçen ülke restoranlarının menülerinde de yer almaya başladığı görülmektedir (Aksoy, Örgün ve Keskin, 2015). Geleneksel Hint beslenme kültürü incelendiğinde, mevsime göre yiyecek-içecek tercihi yapmak etkili bir beslenme planı oluşturmak için önemlidir. Bununla birlikte çalışmalar göstermektedir ki, etkili bir beslenme planı oluştururken mevsimleri göz önünde bulundurmak gerekmektedir; çünkü yiyecekler mevsimlere göre değişiklik göstermektedir (Sarkar, Kumar, Dhumal, Panigrahi ve Choudhary, 2015). Kökeni Hindistan'a dayanan ayurvedaya bakıldığında giyilen kıyafetten yapılan egzersize, yenilen gıdalara içilen içeceklere kadar tüm dış değişimlere uyum sağlamak; sağlıklı bir yaşam için bu sistemle uyum içinde yaşamak gerekmektedir. Ayurveda doğa tıbbı olduğu için dış değişimlerin dikkatli bir şekilde incelenmesi ve gerekli düzenlemelerin buna göre yapılması önem arz etmektedir. (Şener, 2008). Bu çalışmanın amacı; ayurveda sağlıklı beslenme sisteminin öğretileri doğrultusunda, ayurvedik ilkelerden ödün verilmeden yiyeceklerin mevsimsel kullanımlarının dikkate alındığı ve Türk mutfak özelliklerinin de göz önünde bulundurulduğu menü planlamaları yaparak ayurvedayı Türk mutfağına uyarlamaktır.

\section{LITERATÜR TARAMASI}

\section{Ayurveda Felsefesi}

Hindistan'ın en eski geleneksel sağlık sistemlerinden biri olan (Pandey, Rastogi ve Rawat, 2013) ve günümüzde yeni bir tıp dalı olarak kabul edilen ayurveda (Saraç, 2008) MÖ. 2500 lü yıllarda ortaya çıkmış olup (Mukherjee ve Wahile, 2005) "science of life" yani yaşam bilimi anlamını taşımaktadır (Frawley ve Ranade, 2012). Hindistan'daki geleneksel sağlık sistemlerinin hastalıkların engellenmesi ve tedavi edilmesinde metabolik dengenin sağlanmasının önemli olduğuna odaklanmaktadır (Pandey vd., 2013). Bununla birlikte ayurveda bütüncül bir bakış açısıyla yaklaşarak yaşam ve bilinç için yararlı ya da zararlı besinleri, davranışları tanımlayarak hem fiziksel hem ruhsal iyi olma halini 
hedeflemektedir. Beden, zihin ve ruhun bir arada uyumlu olduğu bir varoluşun yaşam amacına uygun olarak nasıl uzun ömürlü olacağının kavranmasını sağlar. Yani hayatın bütününü anlama sanatı olan ayurveda da sağlık nihai bir amaç değil ruhsal ilerleme yolunda gerekli bir araç olarak kabul edilmektedir (Tokyürek, 2014). Ayurveda "insanın kendi potansiyelinin en üst sinırın gerçekleştirirken her yönden dengede kalmasına yardımcı olan bilge sistemler bütünüdür". Ayurveda da bütünsellik önemlidir, çevre, beden, ruh, zihin ve sağlık arasında bir denge ve bütünlük amaçlanmaktadır (Şinik, 2018). 2000'li yıllar itibariyle A.B.D'de oldukça bilinir hale gelen bu sağlık ve beslenme sistemini Dünya Sağlık Örgütü resmi olarak tanımış ve sağlıklı yaşam üzerine olumlu etkileri olduğu bildirilmiştir (Aksoy, Örgün ve Keskin, 2015). Yine Dünya Sağlık Örgütü'nün bir araştırmasına göre gelişmekte olan ülkelerde yaşayan nüfusun $\% 80^{\prime} i$ temel sağlık ihtiyaçları söz konusu olduğunda geleneksel ilaçları tercih etmektedirler (Mukherjee ve Wahile, 2006).

Ayurveda sistemine göre doğanın beş elementten oluştuğu gibi insan da doğayı oluşturan elementlerden meydana gelmiş ve doğa ile arasında bu sayede temel bir ilişki kurulmaktadır. Bu elementler boşluk, hava, ateş, su ve topraktır ve evrendeki her şey bu beş elementten oluşmaktadır. $\mathrm{Bu}$ elementlerin özellikleri yani guna'ları hem evrendeki her maddenin içindeki potansiyeli tarif etmeyi sağlarlar; hem de belli gıdaların ve bazı alışkanlıkların bedenler üzerindeki etkilerinin anlaşılmasını sağlayan pratik uygulamaları barındırmaktadır (Allmendinger, 2019). İnsan vücudunda bu beş elementin dengeli bir şekilde var olması sağlı̆ın, dengesiz olması ise hastalıkların nedeni sayılmaktadır (WHO, 2010).

Ayurveda da önemli bir yer tutan doshalar bir bireyi diğerinden ayıran, kişiye özgü psikobiyokimyasal özellikleri tanımlayan ve kişileri hem fizyolojik açıdan hem de psikolojik açıdan etkileyen enerjiler olarak ortaya çıkmaktadır (Saraç, 2002). Bu enerjiler bedende üç dosha ile temsil edilir; bunlar Vata, Pitta ve Kaphadır (WHO, 2010). Her bireyin doğuştan sahip olduğu baskın bir doshası vardır ve yaşam dengesinin sağlanması için doshaya uygun gıda seçimi, beslenme tarzı, baharat kullanımı, yemek pişirme teknikleri, fiziksel aktiviteler, müzik seçimleri gibi etmenler daha sağlıklı ve uzun bir yaşam için gerekli görülmektedir (Şinik, 2018). Herkes üç dosha ile doğar ve insanların çoğu diğerlerine göre birinci derece baskın, biraz daha az ikinci derece baskın ve daha az baskın olmak üzere üç tip doshayı da bünyesinde barındırmaktadır. İnsanların çok az bir kısmı ise üç doshayı birlikte doğal olarak uyumlu bir şekilde yapılarında bulundurmaktadırlar (Saraç, 2002).

Ayurveda her insanın bünyesinde var olan üç doshayı birbiriyle uyumlu ve dengeli hale getirmektedir. Örneğin Vata olan bir kadın (baskın doshası Vata) kendinde dengeyi sağlamak için Pitta ve Kapha doshasına ait olduğu düşünülen yiyeceklerden yiyebilmekte ve yine bu iki dosha türüne ait aktiviteleri yapabilmektedir (Sondhi, 2010). Ayurveda felsefesinde her vücudun kendine özgü bir dosha oranı vardır ve bu oran dosha testiyle bulunmaktadır. Dosha testindeki sorularla kişilerin dosha seviyesi ortaya çıkmakta ve hangi dosha'ya sahip olduklarına göre de uygun beslenme şekilleri belirlenmektedir (Saraç, 2002).

Vata boşluk ve hava elementlerini temsil etmektedir. "Doshaların kralı” şeklinde bahsedilen vata' nın ana merkezi bağırsaklardır ve diğer iki doshanın dengesini bozabilecek tek doshadır. Vata dengeli olduğunda esneklik, yaratıcılık, hafiflik ve neşe ortaya çıkarken; dengesizliği söz konusu olunca sinirlilik, korku ve endişe belirmeye başlamaktadır. Vata'nın dengesinin bozulmasının nedenleri olarak çiğ ve kuru yiyecekler, lahana, brokoli, karnabahar, kuru bakliyat, yetersiz beslenme, acı ve kekremsi tatlar, seyahat etmek, birden fazla işle aynı anda uğraşmak sayılabilmektedir. Vata dengesiz bir hal aldığında yani yükseldiğinde kilo kaybı, bel ağrısı, uykusuzluk, ciltte kuruluk, gaz, şişkinlik, kabızlık, düzensiz kalp atışı, unutkanlık gibi belirtiler göstermektedir. Ayurveda'nın "Benzer benzer olanı yükseltir, karşıtlar birbirini dengeler" prensibine dayanarak, vata doshası içinde barındırmadığı tam tersi özellikleri uygulayarak dengelenebilmektedir (Allmendinger, 2019).

Pitta ateş ve su elementlerini temsil etmekte ve bu iki elementin özelliklerinin birleşimi olan sıcak, keskin, akışkan, hareketli ve yağlı gibi nitelikleri taşımaktadır. Dengede olduğunda iştahı, canlılığı, ciltte 1şıltıyı, keskin görüşü, zekâyı, anlayışı arttırırken; dengesizleştiğinde öfke, nefret, yılgınlık ve 
iltihaba neden olabilmektedir. Pitta'nın dengesinin bozulmasının nedenleri olarak acı ve yağlı yemekler, ekşi, tuzlu, fermente gidalar, domates, patlıcan, patates, biber, sigara, alkol, öfke, nefret sayılabilmektedir. Pitta dengesiz olduğunda yani yükseldiğinde reflü, mide problemleri, ishal, terleme, baş ağrısı, bitkinlik, asabiyet gibi belirtiler göstermektedir. Dengelenebilmesi için pitta'nın tam tersi olan soğuk, yumuşak, kuru özellikler uygulanabilmektedir (Allmendiner, 2010).

Toprak ve su elementlerini bir arada bulunduran kaphalar dengeli olduklarında kendilerini affedicilik, sevgi, güç, iyi bir bağışıklık sistemi olarak ortaya koyarlarken; dengesiz durumlarında depresyon, bağımlılık, fazla kilo, kabızlık, ödem gibi durumlar gösterebilmektedirler. Dengesizliğinin sebepleri olarak soğuk yiyecek ve içecekler, fazla yemek, yağlı ve ağır yemek, tatlı, tuzlu yiyecekler, ekmek, makarna, börek gibi karbonhidratların aşırı tüketimi, süt, krema, peynir, yoğurt gibi süt ürünleri, aşırı uyku, hareketsizlik sayılabilmektedir. Kapha doshası yükseldiğinde hazımsızlık, öksürük, alerjiler, fazla uyuma, horlama, diyabet, iyi huylu kistlerin oluşumu gibi durumlar yaşanabilmektedir. Sıcak, kuru, sert, berrak, hafif özellikler uygulanarak denge durumu sağlanabilmektedir (Allmendiner, 2010).

\section{Ayurvedik Beslenme Sistemi}

Ayurveda, M.Ö. 3000 yıllarında yazılı hale getirilmiş dünyanın en eski ve en şifalı sağlık sistemlerinden biri olarak kabul edilmektedir (Svoboda, 2004). Burada gidaların nasıl pişirileceğinden, nasıl sunulacağına ve nasıl tüketileceğine kadar beslenme sistemiyle ilgili her şey hakkında detaylı bilgiler bulunmaktadır (Şener, 2008). Bütünsellik ilkesinin hâkim olduğu ayurveda da beslenme yaşamın temel yapı taşlarından birini oluşturmaktadır. (Aksoy vd., 2015). Buna göre evren beş elemente ve bu elementlerin dengesine bağlanmaktadır. Çevredeki her şey bu beş elementin farklı oranlarda birleşiminin bir sonucu olarak belirtilmektedir.

Ayurveda da beş elementin karşılıkları bulunmaktadır. Boşluk elementinin evrendeki karşılığı uzaydır. Baklagiller, taze meyve suları uzay elementince zengindir. Hava elementinin evrendeki karşılığı rüzgârdır. Kuru meyveler, olgunlaşmamış pişmemiş sebzeler, brokoli, lahanagiller, patlıcan, domates gibi sebzeler, kuru fasulye, nohut gibi birçok baklagil hava elementince zengindir. Ateş elementinin evrendeki karşılığı güneştir. Baharatlar (karanfil, tarçın, karabiber, acı biber, zencefil), sarımsak, soğan, ekşi meyveler (ananas, limon, greyfurt, ahududu, böğürtlen), ateş elementince zengindir. Su elementinin evrendeki karşllı̆̆ yağmurdur. Sulu meyveler (karpuz, üzüm, portakal), sulu sebzeler (kabak, salatalık, domates), tuz, süt ürünleri su elementince zengindir. Toprak elementinin evrendeki karşılığı dünyadır. Mineraller, çekirdekler, fındık, fıstık, et, mantar, patates, havuç gibi kök kısımları tüketilen sebzeler, fasulye, kurutulmuş meyveler, buğday, pirinç diğer tahıllar toprak elementince zengindir (Şener, 2008).

\section{Ayurveda'ya Göre Tat Grupları}

Ayurveda beslenme sisteminde doshaları etkileyen altı temel tat bulunmaktadır. Bu tatlar; tatlı (mahdura), ekşi (amla), tuzlu (lavana), keskin-yakıcı (katu), bitter (tikta), kekremsi (kaşaya). Bu altı tat gruplarına dâhil olan yiyecekler Tablo.1 de gösterilmiştir. 
Tablo 1. Altı Tat Grubuna Örnekler

\begin{tabular}{|c|c|}
\hline 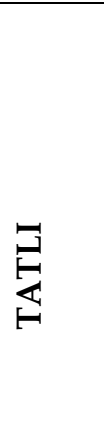 & 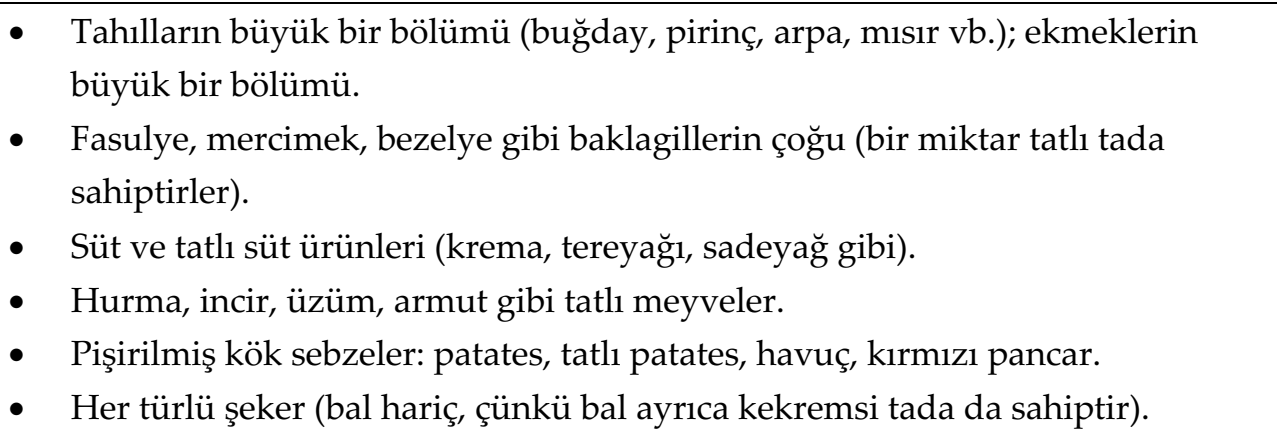 \\
\hline $\begin{array}{l}\text { "⿹\zh26 } \\
\frac{1}{r}\end{array}$ & $\begin{array}{ll}\text { - } & \text { Ekşi meyveler (limon, misket limonu, ekşi portakal vb.). } \\
\text { - } & \text { Yoğurt, peynir, ekşi krema ve kesilmiş sütün suyu gibi ekşi süt ürünleri. } \\
\text { - } & \text { Kültüre edilmiş süt ürünleri dışındaki mayalı ürünler (şarap, sirke, soya sosu) } \\
\text { - } & \text { Karbonik asitli meşrubatlar. }\end{array}$ \\
\hline$\stackrel{?}{\stackrel{D}{P}}$ & $\begin{array}{l}\text { - Her türlü tuz (örneğin deniz tuzu, kaya tuzu). } \\
\text { - } \quad \text { İçerisinde fazla miktarlarda tuz ilave edilmiş besinler (turşular, cipsler vb.) }\end{array}$ \\
\hline 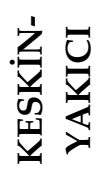 & $\begin{array}{l}\text { - Acı biber, karabiber, hardal tohumu, zencefil, kimyon, sarımsak gibi } \\
\text { baharatlar. } \\
\text { - Turp, soğan gibi sebzeler. }\end{array}$ \\
\hline 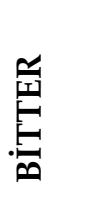 & $\begin{array}{l}\text { - Zeytin, greyfurt gibi meyveler. } \\
\text { - Ispanak gibi yeşil yapraklı sebzeler, beyaz lahana, kabak. } \\
\text { - } \quad \text { Patlıcan, hindiba gibi. } \\
\text { - Çemen, zerdeçal gibi baharatlar. }\end{array}$ \\
\hline$\sum_{\substack{n=1 \\
n}}^{\infty}$ & $\begin{array}{l}\text { - } \quad \text { Baklagiller, fasulyeler, mercimekler. } \\
\text { - } \quad \text { Ceviz, fındık. } \\
\text { - } \quad \text { Filizlenmiş tohumlar, marul ve diğer yeşil yapraklı sebzeler, ravent, çiğ } \\
\text { - } \quad \text { Nebzelerin suyu. } \\
\text { - Nar, elma (az kekremsi), böğürtlenler, Trabzon hurması, ham meyveler. }\end{array}$ \\
\hline
\end{tabular}

Kaynak: Sharma ve Clark (1999: 163-168).

Bu sınıflandırmanın kullanışıyla ilgili kurallar şunlardır;

- Tam bir beslenmenin sağlanması ve dosha dengesinin devam ettirebilmesi için her öğünde her tat grubundan biri bulundurulmalıdır.

- Ayurveda'ya göre tat grupları besinin özelliklerine işaret etmektedir.

- Her tadın dosha üzerinde önemli bir etkisi olduğundan ya dosha'yı artırmakta veya azaltmaktadır.

Tatların dosha'lar üzerindeki etkisi Tablo.2 de gösterilmiştir. 
Tablo 2. Tatların Dosha Grupları Üzerine Etkisi

\begin{tabular}{|l|l|l|l|l|l|l|}
\hline \multirow{2}{*}{} & \multicolumn{6}{|c|}{ TATLAR } \\
\cline { 2 - 7 } & Tatıı & Ekşi & Tuzlu & Acı (bitter) & Kekremsi & Buruk \\
\hline Kapha & Artırır & Artırır & Artırır & Azaltır & Azaltır & Azaltır \\
\hline Vata & Azaltır & Azaltır & Azaltır & Artırır & Artırır & Artırır \\
\hline Pitta & Azaltır & Artırır & Artırır & Artırır & Azaltır & Azaltır \\
\hline
\end{tabular}

Kaynak: Şener (2008:14).

\section{Beden Tiplerine Uygun Beslenme Şekilleri}

Ayurvedaya göre farklı beden tiplerine göre farklı beslenme şekilleri bulunmaktadır. Doshalara göre hangi besinlerin yenilmesi, hangi besinlerden uzak durulması gerektiği tablolarda ayrıntılı bir şekilde verilmiştir. Bazı kişiler iki doshanın hakim olduğu karma beden tipine sahip olabilmektedir. Dosha dengesi bozulduğunda hastalık ortaya çıkmakta, bu hastalığa sebebiyet veren doshanın beslenme ile yeniden düzeltilmesi gerekmektedir. Ayurveda beslenme sistemine bakıldığında en iyi enerji veren yiyecekler taze meyve ve sebzeler ve hububatlardır. Bu gıdalarda doğanın iyileştirci ve besleyici gücünü etkin bir şekilde barındırmaktadırlar. Ayurveda beslenme sisteminde et ve et ürünleri tüketimi pek önerilmemekle birlikte daha çok sebze, meyve, tahıl ve baklagillerden oluşan beslenme sistemi önerilmektedir (Şener, 2008).

\section{Vata Beslenmesi}

Vata'nın düzensiz iştah ve boşaltım, hazımsızlık, gaz/şişkinlik gibi sindirim bozuklukları olduğundan vatalar sebzeleri ve meyveleri çiğ değil pişmiş olarak tüketmelidirler. Gün boyunca sıcak bitki çayları, çorba gibi sulu yiyecekleri tüketmelidirler.

Tablo 3. Vata Dengeleyici Besin Şeması

\begin{tabular}{|c|c|}
\hline 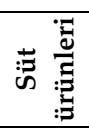 & $\begin{array}{l}\text { Sadeyă̆, süzme peynir, süt kefiri, ekşi krema, yoğurt gibi süt ürünleri vatayı } \\
\text { yatıştırır. Süt kaynatılmış ve } 1 \text { lık ve tek başına tüketilmelidir. }\end{array}$ \\
\hline 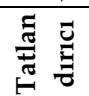 & Pekmez, bal, esmer şeker vata için iyidir. Beyaz şeker tüketimi azaltılmalıdır. \\
\hline$\stackrel{\substack{200\\
}}{\pi}$ & Susam yağı, zeytinyağı, badem yağı, tereyağı vatayı azaltır. \\
\hline 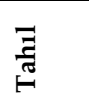 & $\begin{array}{l}\text { Pirinç ve buğday, kinoa çok iyidir. Arpa, mısır, akdarı, karabuğday yulaf alımı } \\
\text { azaltılmalıdır. }\end{array}$ \\
\hline 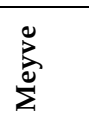 & $\begin{array}{l}\text { Portakal, muz, avokado, kavun, incir, ananas, mango gibi tatlı meyveleri tercih } \\
\text { edilmeli, tüm kurutulmuş meyveler, elma, kızılcık gibi meyveler azaltılmalıdır. }\end{array}$ \\
\hline 苂 & $\begin{array}{l}\text { Kırmızı pancar, bamya, havuç, kuşkonmaz, yer elması, salatalık ve tatlı patates } \\
\text { pişmiş olarak tüketilmelidir. Lahana, brokoliden kaçınmak gerekmektedir. }\end{array}$ \\
\hline 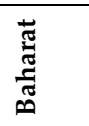 & $\begin{array}{l}\text { Kakule, kimyon, zencefil, tarçın, tuz, karanfil, hardal tohumu ve az miktarda tüketilen } \\
\text { karabiber uygundur. Kırmızı ve acı biber tüketimi azaltılmalıdır. }\end{array}$ \\
\hline 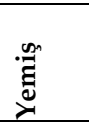 & $\begin{array}{l}\text { Badem, fındık, fıstık, kaju, ceviz, antep fıstığı, susam, dolmalık fıstık, kabak çekirdeği, } \\
\text { ay çekirdeği tercih edilmeli, patlamış mısır tüketilmemelidir. }\end{array}$ \\
\hline 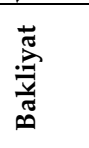 & $\begin{array}{l}\text { Tofu ve maş fasulyesi, kırmızı mercimek hariç bütün baklagil tüketimini } \\
\text { azaltılmalıdır. Bunlar vatayı artırır. }\end{array}$ \\
\hline 苗 & $\begin{array}{l}\text { Yumurta tüketilebilir. Vejetaryen olmayanlar tavuk, hindi ve deniz ürünleri } \\
\text { tüketilebilir. Kırmızı etlerin hiçbiri tüketilmemelidir. }\end{array}$ \\
\hline
\end{tabular}

Kaynak: Sharma ve Clark (1999: 163-168), Sarkar vd., (2015: 97-109) Panigrahi, Şinik (2018: 167-172). 


\section{Pitta Beslenmesi}

Pitta tipi güçlü bir sindirime, açık bir iştaha ve çok miktarda besin tüketme arzusuna sahiptirler. Et ve süt ürünlerini en rahat hazmeden dosha grubudur.

Tablo 4. Pitta Dengeleyici Besin Şeması

\begin{tabular}{|c|c|}
\hline : & $\begin{array}{l}\text { Süt, tereyağı, sadeyağ, soya sütü, lor pitta'nın yatıştııılmasını sağlar. Yoğurt, eski } \\
\text { peynir, ekşi krema, ayrandan kaçınılmalıdır çünkü bunlardaki ekşi tat pitta'yı } \\
\text { aşırılaştırmaktadır. }\end{array}$ \\
\hline 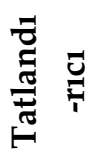 & $\begin{array}{l}\text { Meyve şekeri, esmer şeker gibi tatlandırıcılar pitta için iyidir, ancak bal, pekmez } \\
\text { fazla miktarda alınmamalıdır. }\end{array}$ \\
\hline 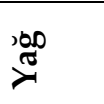 & $\begin{array}{l}\text { Tereyağıı, sadeyă̆, Hindistan cevizi yağı, zeytinyağı en iyi yağlardır. Pitta'lar susam } \\
\text { yağı, badem yağı ve mısır yağı tüketimini azaltmalı çünkü bunlar pitta'yı artırırlar. }\end{array}$ \\
\hline $\bar{\Xi}$ & $\begin{array}{l}\text { Buğday, beyaz pirinç, arpa, yulaf iyidir. Mısır, çavdar, akdarı, esmer pirinç tüketimi } \\
\text { azaltılmalıdır. }\end{array}$ \\
\hline 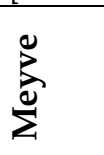 & $\begin{array}{l}\text { Üzüm, kiraz, kavun, avokado, Hindistan cevizi, nar, mango, tatlı portakal gibi tatlı } \\
\text { meyveler tercih edilmeli, greyfurt, zeytin, Trabzon hurması, ham olgunlaşmamış muz } \\
\text { tüketimi azaltılmalıdır. }\end{array}$ \\
\hline $\begin{array}{l}\tilde{N} \\
\stackrel{N}{\mathscr{N}} \\
\omega\end{array}$ & $\begin{array}{l}\text { Kuşkonmaz, balkabağı, havuç, salatalık, lahana, patates, bamya, taze fasulye, yeşil } \\
\text { yapraklı sebzeler, brokoli, karnabahar, kereviz, kabak tüketilmelidir. Acı biber, turp, } \\
\text { domates, kırmızı pancar, soğan, sarımsaktan uzak durulmalıdır. }\end{array}$ \\
\hline 莺 & $\begin{array}{l}\text { Rezene, tarçın, kişniş, kakule uygundur. Az miktarda olmak şartıyla zencefil, } \\
\text { kimyon, karabiber alınabilir. Şu baharatlar pittayı artırırlar: Karanfil, çemen, tuz. Acı } \\
\text { biberden kaçınmak gerekir çünkü pittayı aşırılaştırır }\end{array}$ \\
\hline 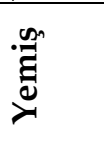 & $\begin{array}{l}\text { Kabak çekirdeği, ay çekirdeği tercih edilmeli, badem ceviz, fındık, kaju fıstığı } \\
\text { tüketilmemelidir. }\end{array}$ \\
\hline$\sum_{\substack{\bar{\pi}\\
}}^{\bar{\pi}}$ & Sadece maş fasulyesi ve mercimek, bezelye tercih edilmelidir. \\
\hline 南 & $\begin{array}{l}\text { Tavuk, hindi yenilebilir. Kırmızı et, deniz ürünleri, yumurta sarısı pitta'yı artırır. } \\
\text { (Yumurta beyazı pittayı artırmaz). }\end{array}$ \\
\hline
\end{tabular}

Kaynak: Sharma ve Clark (1999: 163-168), Sarkar vd., (2015: 97-109) Panigrahi, Şinik (2018: 167-172).

\section{Kapha Beslenmesi}

Kapha beden tipindeki kişiler genellikle sindirimleri yavaştır, iştahsızdırlar, şişkinlik ve aşırı kilo eğilimlidirler. Bu yüzden metabolizmalarını hızlandırmak, vücuttan su atmak için baharat kullanımı ekstra önemlidir.

Ayurveda beslenmesine göre gerçekte en iyi enerji veren gidalar taze meyveler, sebzeler ve hububattır. Bu gıdalarda doğanın iyileştirici ve besleyici gücünü etkin şekilde barındırmaktadırlar. Ayurveda beslenme sisteminde bazı kesin katı kurallar vardır. Bazı besinler bazı besinlerle asla karıştırılamamakta ve birlikte tüketilmesi uygun bulunmamaktadır. Örneğin; döner- ayran, İskender kebap, yoğurtlu meze-balık gibi. Bu besinler Tablo.5'te gösterilmektedir. 
Tablo.5 Kapha Dengeleyici Besin Şeması

\begin{tabular}{|c|c|}
\hline 䓅茪: & $\begin{array}{l}\text { Süt ürünleri azaltılmalı, az yağlı süt tercih etmelidirler. } \\
\text { Yoğurt, dondurma, tereyağı, peynir, kaymak gibi ürünlerden kaçınılmalıdır. }\end{array}$ \\
\hline 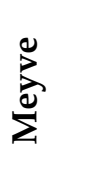 & $\begin{array}{l}\text { Elma, armut, Trabzon hurması, nar, gibi hafif kekremsi meyveler tüketilmelidir. } \\
\text { Üzüm, ananas, incir, bağdat hurması, avakado, Hindistan cevizi, kavun gibi çok tatlı } \\
\text { ve ekşi meyveler azaltılmalıdır. Bunlar kapha'yı artır. }\end{array}$ \\
\hline 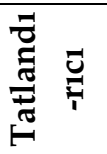 & $\begin{array}{l}\text { Kekremsi tada sahip olan bal, kapha'yı azaltması bakımından iyiyken buna karşın } \\
\text { beyaz şeker, meyve şekeri, kapha'yı artırırlar. }\end{array}$ \\
\hline 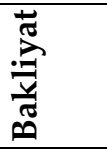 & $\begin{array}{l}\text { Kuru fasulye, sarı mercimek, kırmızı mercimek tüketilmesi uygunken soya fasulyesi } \\
\text { ve tofu tüketiminden uzak durulmalıdır. }\end{array}$ \\
\hline 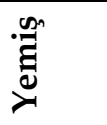 & Fındık, fıstık, susam türü şeylerden uzak durulmalıdır. \\
\hline Е & $\begin{array}{l}\text { Arpa, akdarı, mısır, çavdar, karabuğday kaphalar için iyidir. Ancak buğday, yulaf, } \\
\text { pirinç alımı azaltılmalıdır çünkü bunlar kapha'yı artırırlar. }\end{array}$ \\
\hline 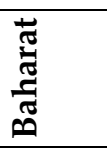 & Tuz hariç hepsi uygundur. \\
\hline ڤN & $\begin{array}{l}\text { Domates, salatalık, bamya, tatlı patates, yer elması ve kabak dişındaki tüm sebzeler } \\
\text { uygundur. }\end{array}$ \\
\hline 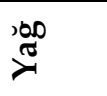 & Mısır özü, zeytinyağı, kanola, ayçiçek, badem yağı kullanımı uygundur. \\
\hline 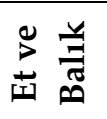 & $\begin{array}{l}\text { Et yenmesi önerilmez. Etsiz yapamayanlar hindi, tavuğun beyaz etini yiyebilirler. } \\
\text { Deniz mahsullerinden kaçınılmalıdır. }\end{array}$ \\
\hline
\end{tabular}

Kaynak: Sharma ve Clark (1999: 163-168), Sarkar vd., (2015: 97-109) Panigrahi, Şinik (2018: 167-172).

Tablo 5. Ayurveda Beslenme Sistemine Uygun Olmayan Besin Eşleştirmeleri

\begin{tabular}{|l|l|}
\hline Besinler & Eşleştirme \\
\hline Meyveler & Tek başına tüketilmelidirler. \\
\hline Süt Ürünleri & Tavuk, balık et ile eşleştirilemezler. \\
\hline Yumurta & $\begin{array}{l}\text { Süt ürünleri, balık, et, meyve ile } \\
\text { eşleştirilemezler. }\end{array}$ \\
\hline
\end{tabular}

Kaynak: Allmendinger, (2019:112-113).

Ayurveda da bazı gıdaların belli başlı zararlı, negatif etkilerini ortadan kaldırmak için gıda antidotları yani o gidaların panzehirleri olacak baharatlar kullanılmaktadır. Antidotlar yemek hazırlarken veya tüketirken aynı anda kullanırlar. Aşağıda Tablo 6 'da listesi verilen gıdalar antidotlarıyla kullanıldığında sıralanan olumsuz etkileri ortadan kalkmaktadır. 
Tablo6. Gıda Antidotları Şeması

\begin{tabular}{|c|c|c|}
\hline Gidalar & Negatif Etki & Antidot (negatif etkiyi ortadan kaldırıcı) \\
\hline & Tahıllar/ Bakliyat & \\
\hline Yulaf & Yağ oranını artırır. Kaphayı artırır. & Zerdeçal, kimyon veya hardal tohumu \\
\hline Pirinç & Yağ oranını artırır. Kaphayı artırır. & Karanfil veya tane karabiber \\
\hline Buğday & Yağ oranını artırır. Kaphayı artırır & Zencefil \\
\hline \multirow[t]{2}{*}{ Baklagiller } & Gaz üretir. Vatayı artırır. & Sarımsak, karanfil, zencefil, tuz, acı k.biber \\
\hline & Sebzeler & \\
\hline Lahana & Gaz üretir. & Ayçiçeği yağında zerdeçal ve hardal \\
\hline Sarımsak & $\begin{array}{l}\text { Midede yanma, ateş basması pitta } \\
\text { rahatsılzlıklarına neden olur. }\end{array}$ & Muskat, limon \\
\hline Soğan & Gaz üretir. & Tuz, limon, yoğurt, hardal tohumu \\
\hline Yeşil salata & Gaz üretir. & Zeytinyağ1 ve limon suyu \\
\hline Patates & Gaz üretir. & Sade yağ ve tane karabiber \\
\hline \multirow[t]{2}{*}{ Domates } & $\begin{array}{l}\text { Mukusun ve yağ oranının artması } \\
\text { kapha rahatsızlıklarına neden olur. }\end{array}$ & Lime limonu veya kimyon \\
\hline & Süt ürünleri & \\
\hline Peynir & $\begin{array}{l}\text { Mukusun ve yağ oranının artması } \\
\text { kapha rahatsızlıklarına neden olur. }\end{array}$ & Karabiber, K. Acı biber \\
\hline Yoğurt & $\begin{array}{l}\text { Mukusun ve yağ oranının artması } \\
\text { kapha rahatsızlıklarına neden olur. }\end{array}$ & Kimyon veya zencefil \\
\hline \multirow[t]{2}{*}{ Dondurma } & $\begin{array}{l}\text { Mukusun ve yağ oranının artması } \\
\text { kapha rahatsızlıklarına neden olur. }\end{array}$ & Karanfil veya kakule \\
\hline & Meyveler & \\
\hline Avokado & $\begin{array}{l}\text { Mukusun ve yağ oranının artması } \\
\text { kapha rahatsızlıklarına neden olur. }\end{array}$ & Zerdeçal, limon, sarımsak, karabiber \\
\hline Muz & $\begin{array}{l}\text { Mukusun ve yağ oranının artması } \\
\text { kapha rahatsızlıklarına neden olur. }\end{array}$ & Kakule \\
\hline K.meyveler & Vücut kuruluğunu ve vatayı artırır. & Suda bekletildikten sonra tüketilmelidir. \\
\hline \multirow[t]{2}{*}{ Karpuz } & Vücutta su tutulmasina sebep olur. & Kırmızı acı biber ve tuz \\
\hline & Et ve Balık & \\
\hline Balik & Midede yanma. Pittayı artırır. & Muskat, lime limonu, kişniş \\
\hline Kirmizi et & Sindirimi zordur. & Arnavut biberi, karanfil, kırmızı acı biber \\
\hline Yumurta & Kapha ve pittayı arttırır. & Maydanoz, soğan, zerdeçal \\
\hline
\end{tabular}

Kaynak: Şener (2008: 61-63), Lad (2015).

Ayurveda sağlıklı besin derken, yemeklerin hazırlanış sırasında mümkün olan en kaliteli besin maddelerinin kullanılmasını önermektedir. Genel olarak çiğ besinlerin yerine pişmiş olarak tüketilmesini önerir, pişmiş olan besinlerin sindirimi daha kolaydır, çünkü pişirme, sindirim sürecinin ilk adımı sayılır (Sharma ve Clark, 1999). 
"Ayurveda" olarak adlandırılan antik tıp bilimi sisteminde pişirme işlemi sonucunda gıda kompozisyonu değişerek vücuda olan yararlılığının azaldığını keşfedilmiştir. Örneğin; domatesin içindeki likopenin pişmesiyle besleyicilik değerinin artması, soğanın çok pişirilmesinin besin kayıplarına neden olduğu, sulanmış soğan tüketiminin de asitliğe neden olduğu için bu besinlerin bu şekilde pişirilmesi tavsiye edilmemektedir. (Ailawadi, 2018).

\section{YÖNTEM}

Bu çalışmada, kanaatlerin ve algıların daha kolay öğrenilmesini sağlayan nitel bir araştırma yöntem olarak belirlenmiştir (Yıldırım ve Şimşek, 2013). Çalışmanın ilk bölümünde Ayurveda felsefesini ve beslenme sistemini kapsayan bir literatür taraması yapılmıştır. Literatür taraması yapıldığında görülmüştür $\mathrm{ki}$; ayurveda sistemine ve Türk mutfağına uyarlanmış menüler ve yemekler bulunmamaktadır. Buradan hareketle literatürde ve alanda eksikliğin giderilmesi adına bu tür bir çalışma yapılmasının uygun olacağı düşünülmüş ve ayurveda beslenme sistemi dikkate alınarak Türk mutfağına uygun yemekler içeren menüler oluşturmak ve oluşturulan menüleri geliştirmek amacıyla eylem odaklı uygulama araştırması gerçekleştirilmiştir (Aksoy, 2015). Tariflerin oluşturulurken Gastronomi ve Mutfak Sanatları ve Beslenme ve Diyetetik bölümü hocalarının görüşleri alınmıştır. Bu amaçla bütün doshalara uygun, günümüzde restoran menülerinde servis edilen yemeklerin sırası göz önünde tutularak sonbahar-kış için menüler planlanmış ve menüdeki yemekler bu çalışmayı yapan Gastronomi bölümü hocaları tarafından tek tek denenerek standart tarifleri oluşturulmuş ve menüde yer alan yemekler tariflerine uygun olarak hazırlanarak resimleri çekilmiştir. Bu sıralama çorba, soğuk başlangıçlar, sıcak başlangıçlar, ana yemek, tatlıdan oluşmaktadır. Yemekler dört porsiyon olacak şekilde hesaplanmıştır (Altınel, 2017).

\section{BULGULAR}

\section{Doshalar İçin Ayurvedik Sonbahar-Kış Öğle Menüsü Örneği}

Ayurveda da ana öğünün öğlen yemeği olmasını uygun bulunmaktadır. Sabah kahvaltısının ve akşam yemeğinin daha hafif olması tercih etmektedir. Kahvaltı öğünün atlanıp direkt öğlen yemeğinin yenmesi uygun görünmektedir. Türk beslenme kültüründe kahvaltı öğününde çorba içilmesi çok yaygındır. Çorba hem başlangıç hem de ana öğün yemeği olarak tüketilmektedir. Bununla birlikte menülerde yer alan tarhana çorbasının Türk mutfak kültüründe yeri ve önemi vardır (Büyüktüncer ve Yücecan, 2009). Bu durum göz önünde bulundurularak üç dosha grubuna uygun öğleyin servis edilebilecek ayurvedik menü planı oluşturulmuştur. Yemeklerdeki değişimler ve uyarlamalar Tablo 1, 2, 3, 4, 5, 6 göre yapılmıştır.

Menüdeki yemekler, Türk mutfak kültürüne göre uyarlanmış olup;

- Çorba,

- Soğuk başlangıçlar,

- Sicak başlangıçlar,

- Ana yemek,

- Tatlı veya meyveden oluşmaktadır. Her üç dosha içinde yapılan menü ayurveda beslenme sistemi dikkate alınarak Türk yemeklerine uyarlanmıştır (Altınel, 2017).

\section{Vata Menü}

Vatalar genellikle sonbahar-kış mevsimlerinde sindirim, boşaltım sistemlerinde düzensiz iştah, gaz, şişkinlik, kuruluk sıklıkla görülür. Bu yüzden vatalar sıcak, ağır ve nemli besinlerle ve tatlı, ekşi, tuzlu tatlar içeren besinlerle beslenmelidirler. Sıcak çorba, sulu yemekler, bulgur, pirinç gibi nemli 
tahıllar, havuç, pancar gibi kök sebzeler, maş fasulyesi gibi tahıllar, süt ve süt ürünleri gibi besinlerle beslenmeleri sindirim sistemlerine iyi gelecektir. Vataların bu durumları göz önünde tutularak sonbahar-kış mevsimi için aşağıdaki menü oluşturulmuştur.

- Çorba: Mor Havuç (Pancar) Tarhanası

- Soğuk başlangıçlar: Maş piyazı

- Sıcak başlangıçlar: Yeşil Mercimekli İçli Köfte

- Ana yemek: Ekşili Kuru Bamya Yemeği

- Tatlı: Havuçlu Kakuleli irmik Helvası

\section{Mor Havuç (Pancar) Tarhanası}

Vatalara özellikle kök sebzelerden kırmızı pancar yenmesi önerilmektedir. Süt grubunun hepsi vatlara iyi gelmekte bu özelliğinden dolayı pancar ve mor havuçtan yapılan bu tarhana vatalar için iyi bir sonbahar- kış yemeği sayılabilir. Tarhana Türk Mutfağında en çok sevilen en çok tüketilen çok farklı çeşitlerde yapılan protein bakımından zengin bir çorbadır. Bu fermente çorba protein ve antioksidan bakımından besleyicilik değeri düşünüldüğünde vatalar için iyi bir seçenek olduğu düşünülebilir. Bu çorba kırmızı pancardan yapıldığından vata ve kaphalara uygunken pittalara uygun olmamaktadır.

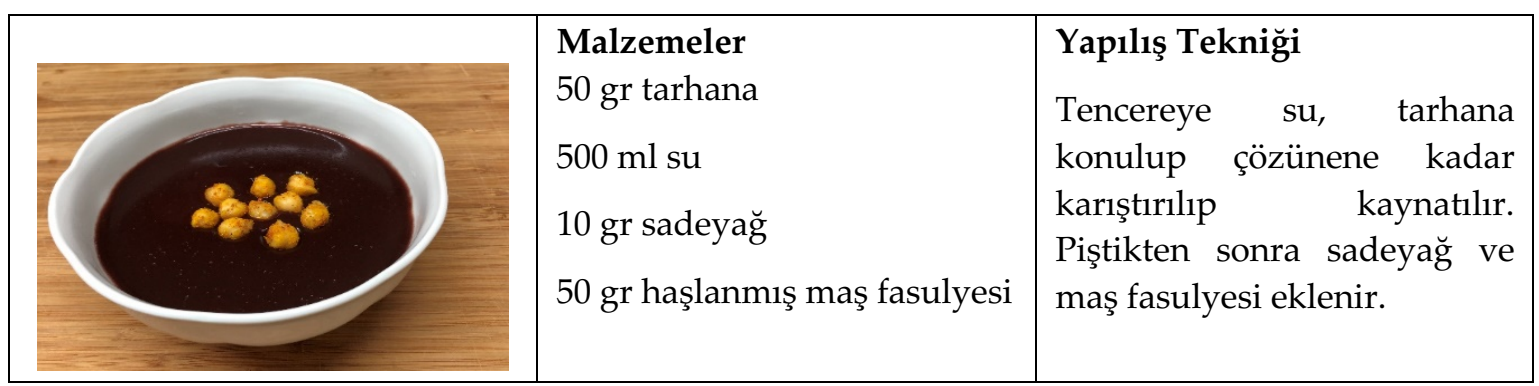

\section{Maş Piyazı}

Bitkisel protein bakımından zengin olan maş fasulyesi bütün dosha grupları için uygundur. Vatalar için maş fasulyesi dışındaki diğer bakliyatlar gaz yapıcı özelliklerinden dolayı önerilmediğinden maş fasulye salatası uygun bulunmuş ve salatanın içindeki diğer yeşillikler, baharatların vatayı azaltıcı etki göstermesi açısından önemlidir. Özellikle yağ ve ceviz vatalara iyi gelen yiyeceklerdir. İçeriğindeki kimyon ve kişniş gaz ve şişkinliği önleyerek vatayı yatıştırıcı etki gösterirler. Vataların beslenme sistemine uygun olarak hazırlanan tarifte birkaç içerik değişikliği yapılarak kapha ve pittalar için uygun hale getirilebilir. İçerikteki ceviz ve maydanoz çıkarıldığında her iki dosha içinde rahatlıkla tüketilebilir. Türk mutfağında da maş fasulyesinin piyaz (salata) şeklinde yaygın olarak tüketilmektedir.

\begin{tabular}{|l|l|l|}
\hline & $\begin{array}{l}\text { Malzemeler } \\
200 \text { haşlanmış maş fasulyesi } \\
20 \text { gr maydanoz, dereotu, } \\
\text { nane, kişniş } \\
50 \text { gr yeşil soğan, kırmızıbiber } \\
50 \text { gr yeşilbiber, nar, ceviz } \\
40 \text { gr kaşığı nar ekşisi, } \\
\text { zeytinyağı } \\
1 / 2 \text { adet limon suyu } \\
5 \text { gr Tuz, 2.5 gr kimyon }\end{array}$ & $\begin{array}{l}\text { Yapılış tekniği } \\
\text { Maş fasulyesi, ince doğanmış } \\
\text { taze soğan, kırmızı biber, yeşil } \\
\text { biber, maydanoz, nane, } \\
\text { dereotu, kişniş bir kâsede } \\
\text { karıştırılır. Limon suyu, } \\
\text { zeytinyağı, nar ekşisi, tuz, } \\
\text { kimyon karıştırılıp sos yapılır. } \\
\text { Bütün malzeme bir kâsede } \\
\text { birleştirilir üzerine sos } \\
\text { dökülüp güzelce karıştırıllır. } \\
\text { En üste nar taneleri serpilir. } \\
\text { Servis edilir. }\end{array}$ \\
\hline
\end{tabular}




\section{Yeşil Mercimekli İçli Köfte}

Türk mutfağında ara sıcak olarak tüketilen içli köfte en sevilen yiyecekler içerisinde bulunmaktadır. Ayurveda beslenmesine uygun olması açısından, iç dolgusunun yeşil mercimekle yapılması hem protein hem lezzet bakımından kıymaya eş değer yakınlıkta olması dikkate alınarak yapılmıştır. Ayurveda da daha çok vejetaryen yemeklerin tercih sebebi olması bu yiyeceğin rahatlıkla tüketimi açısından bütün doshalara uygun hale getirilebilir. Örneğin, içindeki ceviz ve maydanoz çıkarıldığında ve yumurta beyazıyla yapıldığında pittalara uygun hale gelmektedir.

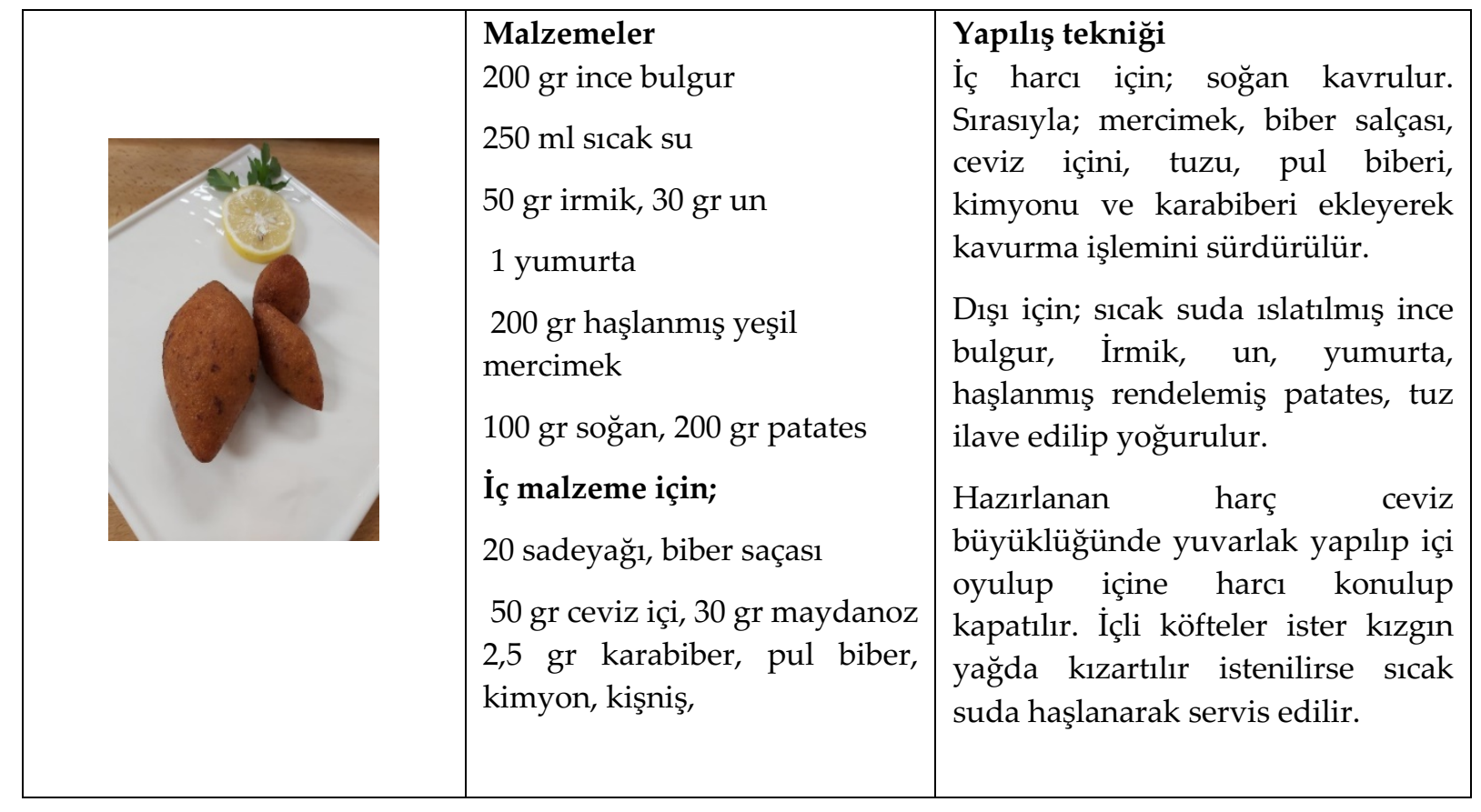

\section{Ekşili Kuru Bamya Yemeği}

Özellikle sindirim problemi yaşayan vatalar için bu yemeğin sindirim kolaylığı sağlaması açısından vatalara çok uygun olduğu düşünülmüştür. Ayrıca içinde bol ekşilik barındırdığı için vatayı azaltıcı etki göstermektedir. Vejetaryen olmayanlar kuzu eti veya tavuk etiyle birlikte de pişirebilir.

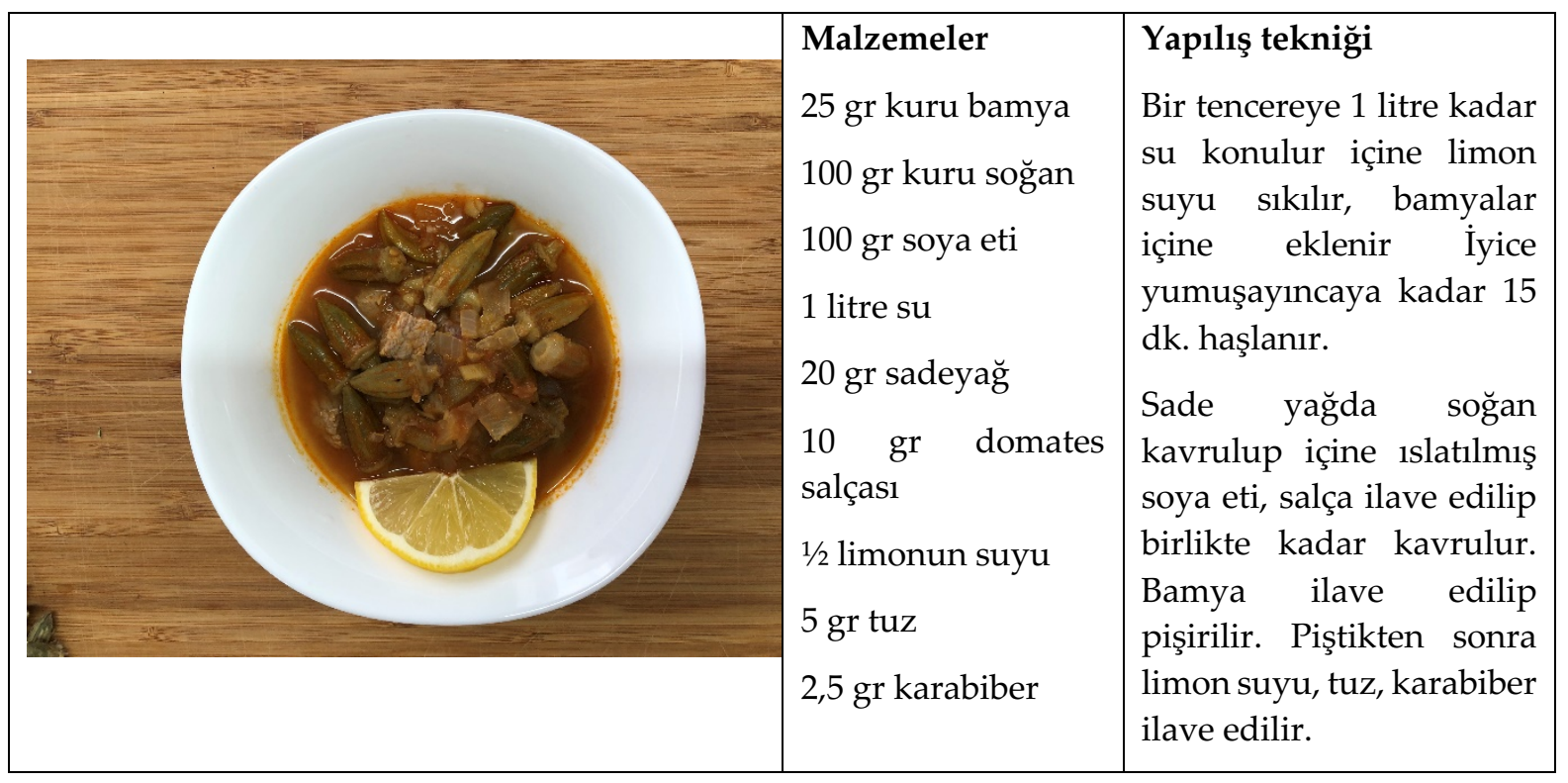




\section{Havuçlu Kakuleli İrmik Helvası}

Hem Hint mutfağında hem Türk mutfağında sevilerek tüketilen bu tatlı her iki mutfağa göre hazırlanmıştır. İçindeki kakule, zerdeçal ve tarçın vatayı ve kaphayı dengeler. Bu tatlı her üç dosha içinde uygun şekilde hazırlanabilir. Süt grubu yiyecekler vatayı yatıştırdığı için tüketimi önerilmektedir. Kaphalar için yapıldığında süt yerine badem sütü veya soya sütü kullanımı birde şeker yerine bal kullanımı kaphayı dengeleme ve azaltma açısından önemlidir.

\begin{tabular}{|c|c|c|}
\hline is & $\begin{array}{l}\text { Malzemeler } \\
200 \text { gr havuç, } 500 \mathrm{ml} \text { süt } \\
20 \text { gr sadeyağ, } 100 \text { gr irmik } \\
50 \text { gr esmer şeker } \\
3 \text { adet kakule, 2,5 gr zerdeçal } \\
1 \text { adet çubuk tarçın } \\
20 \text { gr iç badem, } 20 \text { gr antep } \\
\text { fistığ } 1\end{array}$ & $\begin{array}{l}\text { Yapılış tekniği } \\
\text { Rendelenmiş havuç sadeyağ } \\
\text { da kavrulur. } 1 \text { ² süt eklenip } \\
\text { havuçlar sütü çekinceye } \\
\text { kadar pişirilir. İrmik katılıp } \\
\text { kavrulur. Sütün diğer kısmı } \\
\text { şeker, kakule ve kak tarçın } \\
\text { ilave edilip sütü iyice çekene } \\
\text { kadar pişirilir. Üzerine } \\
\text { badem, antep fıstığı ilave } \\
\text { edilip servis edilir. }\end{array}$ \\
\hline
\end{tabular}

\section{Pitta Menü}

Pitta tipi açık iştahlı ve güçlü bir sindirime sahiptir. Aynı zamanda reflü, mide asitliği, hazımsızlık eğilimindedirler. Bu yüzden vatalar sıcak, ağır, yağlı besinlerle ve tatlı, bitter, kekremsi tatlar içeren besinlerle beslenmelidirler. Sıcak çorba, sulu yemekler, bulgur, pirinç gibi nemli tahıllar, bitter yeşil yapraklı sebzeler, kereviz, sıcak baharatlı süt gibi yiyecekler tüketmelidirler. Pittaların bu durumları göz önünde tutularak sonbahar-kış mevsimi için aşağıdaki menü oluşturulmuştur.

- Çorba: Zerdeçallı Sadeyağlı Süzme Mercimek Çorbası

- Soğuk başlangıçlar: Zeytinyağlı Zencefilli Kereviz

- Sıcak başlangıçlar: Rezeneli Mücver

- Ana yemek: Kulak Aşı Lorlu Mantı

- Tatlı: Kakuleli Tarçınlı Basmati Pirinçli Sütlaç

\section{Zerdeçallı Sadeyağlı Süzme Mercimek Çorbası}

Bu çorba bütün dosha tipleri için uygundur. Besin değeri yüksek olan bu çorba hem Hint hem Türk menülerinde yer almaktadır. Kimyon, zerdeçal, kişniş bütün doshaları dengeleme pittayı da azaltma etkisine sahiptir. Kimyon, kişnişin gaz ve şişkinlik önleyici özelliği zerdeçalın ve kırmızı biberin metabolizmayı hızlandırıcı etkisinden dolayı pittalar için iyi bir tercih unsuru haline gelmektedir.

\begin{tabular}{|l|l|l|}
\hline Malzemeler & $\begin{array}{l}\text { Yapılış tekniği } \\
100 \text { gr sarı mercimek, soğan } \\
\text { Doğranmış soğan, havuç, } \\
\text { patates, sarımsak sadeyağda } \\
\text { kavrulur. Üzerine mercimek } \\
\text { ve su ilave edilir, iyice } \\
\text { yumuşayana kadar pişirilir. } \\
1 \text { diş sarımsak, 20 sadeyağ, } \\
1 \text { litre su } \\
2 \text { gr zerdeçal, kimyon, } \\
\text { zencefil, kişniş, kırmızı toz } \\
\text { biber }\end{array}$ & $\begin{array}{l}\text { baharatlar ve tuz ilave edilir. } \\
\text { Blenderdan çekilir. Servis } \\
\text { edilir. }\end{array}$ \\
\hline
\end{tabular}




\section{Zeytinyağlı Zencefilli Kereviz}

Pittalara için en uygun olan sebzelerin birleşimine sahip bu yemek özellikle kış aylarında pittanın dosha dengesini sağlamasına faydalı olacağı düşünülmektedir. Kış mevsim menülerinde sıkça yer alan zeytinyağlı yemeklerinden biridir. Kereviz, kaphalar içinde iyi bir tercih iken vatalara uygun bir yiyecek değildir.

\begin{tabular}{|l|l|l|}
\hline & $\begin{array}{l}\text { Malzemeler } \\
2 \text { adet kereviz } \\
100 \text { gr havuç, soğan, bezelye } \\
10 \text { gr taze zencefil, 1/2 limon } \\
20 \text { gr toz şeker, } 40 \text { gr } \\
\text { zeytinyağı, } 5 \text { gr tuz }\end{array}$ & $\begin{array}{l}\text { Yapılış tekniği } \\
\text { Kereviz soyulup enlemesine } \\
\text { ortadan ikiye bölünür. } \\
\text { Zeytinyağında ilk olarak } \\
\text { doğranmış havuç ve zencefil, } \\
\text { sirasıyla soğan, bezelye } \\
\text { kavrulur. Kereviz, patates, } \\
\text { şeker, limon suyu, su ilave } \\
\text { edilip pişirilir }\end{array}$ \\
\hline
\end{tabular}

\section{Rezeneli Mücver}

Rezene özellikle sindirim açısından pittayı dengeleyici etkiye sahiptir. Rezene her üç doshayı da dengelediği için bütün doshalar bu yemekte bazı değiş̧iklikler yaparak tüketebilirler. Örneğin; vatalalar için yapıldığında yumurta beyazı yerine sarısıyla birlikte kullanılabilir. Birde nohut unu yerine buğday unu kullanılması uygun olacaktır. Nohut vatalar için uygun bir malzeme değildir.

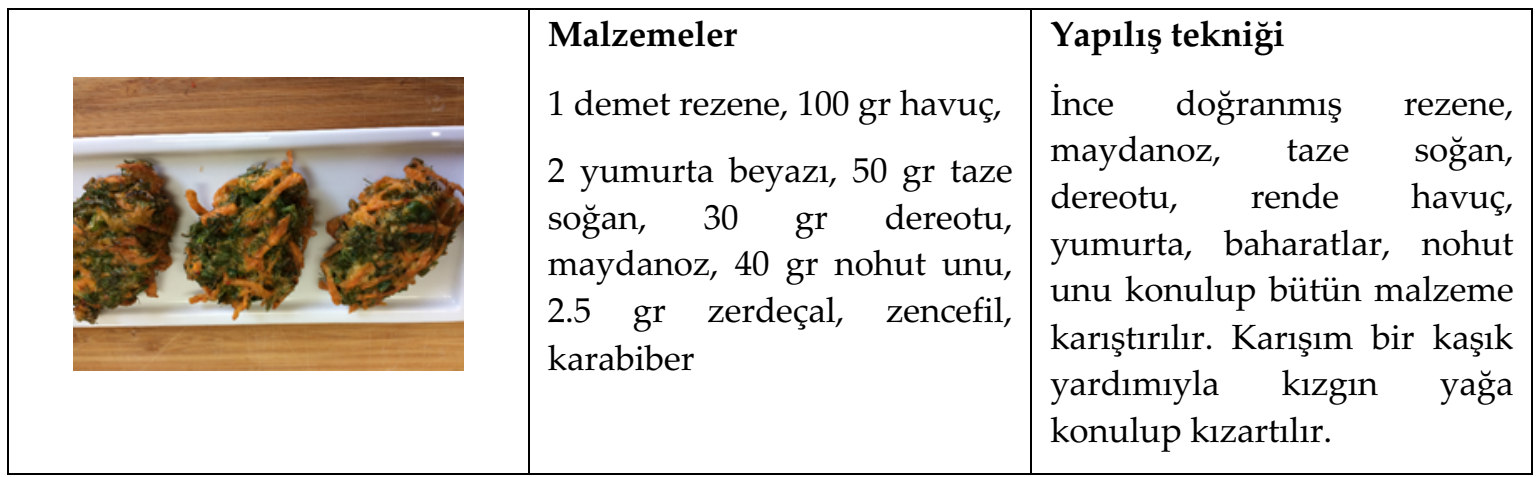

\section{Kulak Aşı Lorlu Mantı}

$\mathrm{Bu}$ yemeğin içindeki malzemelerde bazı değişiklikler yapılarak bütün dosha grupları için ideal bir yemek seçimi olabilir. Bu mantıda kullanılan lor Hindistan'da sıkça kullanılan bizde de süt kestirilerek yapılan süt loruyla yapılmıştır. Vatalara uygun olabilmesi için içindeki nohut unun çıarılması ve yumurta beyazı yerine bütün yumurta kullanılması daha uygun olacaktır. Vatalar Ceviz ve yoğurt ilavesi yaparak tüketebilirler. 


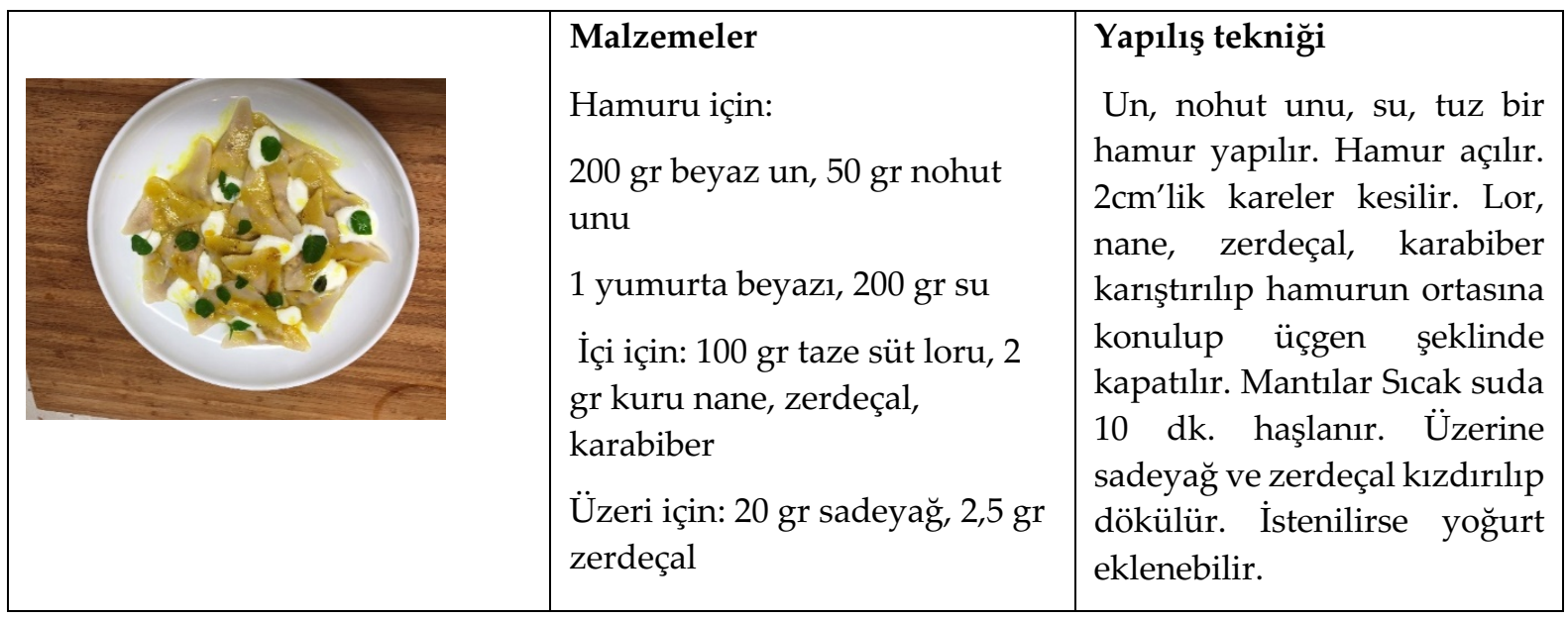

\section{Kakuleli Tarçınlı Basmati Pirinçli Sütlaç}

Süt grubunu en iyi hazmeden dosha grubu pitta olmasına rağmen vatalar içinde uygun bir tatlı olan sütlaç kaphalar için badem sütüyle ve şeker yerine balla hazırlandığında bütün doshalar için uygun hale gelebilmektedir. İçindeki kakule, tarçın ile de bütün doshaları dengeleyici bir özellik oluşturmaktadır. Bu tatlı da süsleme olarak kullanılan badem, fıstık gibi kuruyemişler pittayı yükselttiği için kullanılmaması önerilmekte, vatalar için kullanılmasında bir sakınca görülmemektedir.

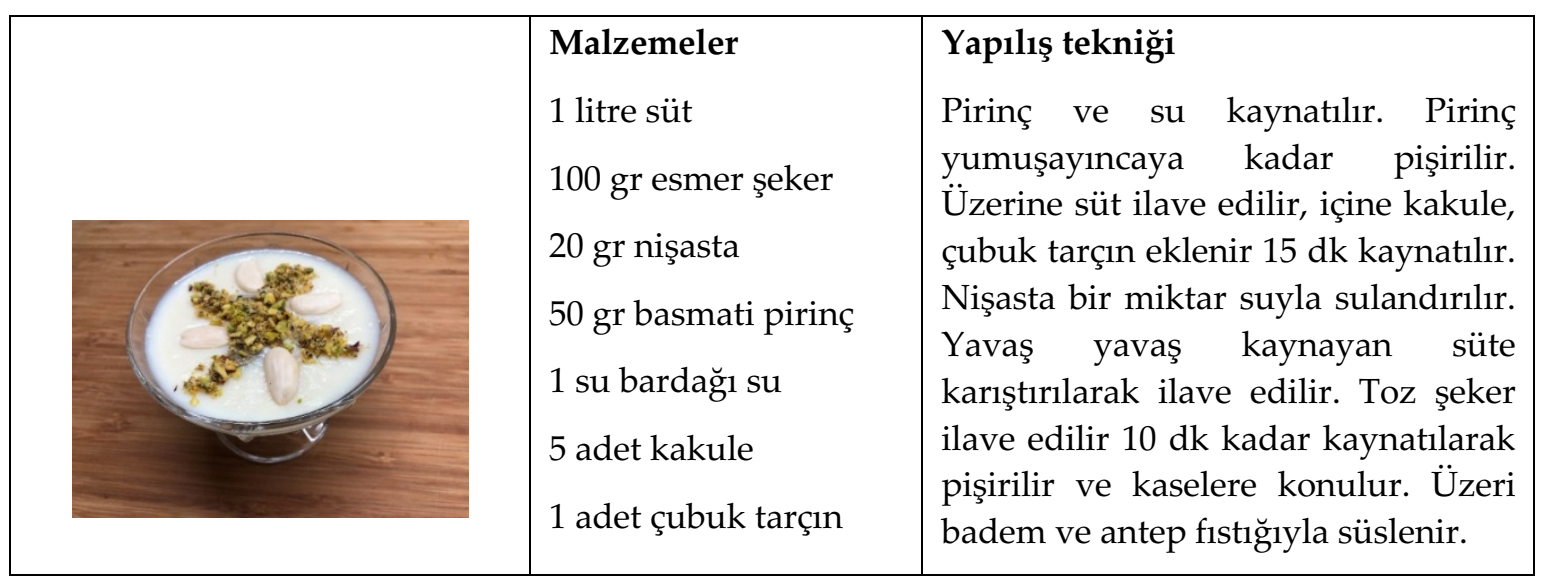

\section{Kapha Menü}

Kapha tipi kişilerin sindirim sistemi genellikle yavaş çalışmaktadır. Bu yüzden aşırı kiloya ve şişkinliğe sahiptirler. Sıcak çorba, sulu sebze yemekleri, hafif tatlılar tüketmeleri gerekmektedir. Pittaların bu durumları göz önünde tutularak sonbahar-kış mevsimi için aşağıdaki menü oluşturulmuştur.

- Çorba: Kızılcık Tarhanası

- Soğuk başlangıçlar: Fasulye piyazı

- Sıcak başlangıçlar: Yeşil Mercimekli Börek

- Ana yemek: Zerdeçallı Nohutlu Kapuska

- Tatli: Zerde 


\section{Kız1lc1k Tarhanası}

Kekremsi bir meyve olan kızılcık kapha ve pittayı azaltıcı etkiye sahiptir. Fermente bir üründen yapılan bu çorba içine eklenen nohut sayesinde protein bakımından daha da zenginleştirilmiştir.

\begin{tabular}{|l|l|l|}
\hline & Malzemeler & Yapılış tekniği \\
& $50 \mathrm{gr}$ tarhana \\
$500 \mathrm{ml} \mathrm{su}$ & $\begin{array}{l}\text { Tencereye su, tarhana } \\
\text { konulup çözünene kadar } \\
\text { karıştırılıp kaynatılır. } \\
\text { Piştikten sonra sadeyağ ve } \\
\text { nohut eklenir. }\end{array}$ \\
\hline 50 gr sadeyă̆ & \\
\hline
\end{tabular}

\section{Fasulye Piyazı}

Fasulye piyazı kaphalar için iyi bir soğuk başlangıç yemeği olarak düşünülmüştür. İçeriğindeki kimyon ve sarımsak sayesinde fasulyenin gaz yapıcı özelliği azaltılmıştır. Bu etkisi azaltıldığı içinde pittalara ve vatalara da uygun hale getirilmiştir. Kaphalar için buğday unu uygun olmadığından çavdar ekmeği tercih edilmiştir. Pittalar için çavdar ekmeği yerine buğday ekmeği tercih edilmesi daha uygun olacaktır.

\begin{tabular}{|c|c|c|}
\hline & $\begin{array}{l}\text { Malzemeler } \\
300 \text { gr haşlanmış kuru fasulye } \\
2 \text { diş sarımsak, } 60 \text { gr tahin } \\
20 \text { gr üzüm sirkesi, } 40 \text { gr sıcak } \\
\text { su } \\
2.5 \text { gr pul biber, } 5 \text { gr tuz, } 5 \text { gr } \\
\text { kimyon } \\
30 \text { gr maydanoz, } 4 \text { dilim } \\
\text { çavdar ekmeği }\end{array}$ & $\begin{array}{l}\text { Yapılış tekniği } \\
\text { Ezilmiş arımsak, tahin, sirke, } \\
\text { pul biber, kimyon, tuz, sıcak } \\
\text { sıcak su hepsi güzelce çırpılır. } \\
\text { Sosun yarısı fasulyelerle } \\
\text { karıştırılır. } \\
\text { Ekmeğin üzerine fasulyeler } \\
\text { yerleştirilir. Ayrılan sosun } \\
\text { diğer yarısı fasulyelerin } \\
\text { üzerine gezdir. Doğranmış } \\
\text { maydanoz ve pul biberle üzeri } \\
\text { süslenir. Servis edilir. }\end{array}$ \\
\hline
\end{tabular}

\section{Mercimekli Börek}

Ayurveda beslenme sisteminde et tüketimi önerilmediğinden dolayı bitkisel protein bakımından zengin olan bakliyat grubundan yararlanarak hazırlanan yiyecekler önem arz etmektedir. Bu börekteki ana malzeme olan yeşil mercimek besleyicilik değeri ve lezzet bakımından ete eş değer olduğu düşünülerek bu menüye ilave edilmiştir. Bütün doshalar için uygundur. İçindeki kimyon, kişniş mercimeğin gaz yapıcı etkisini azaltarak daha kolay sindirilmesini sağlayacaktır. 


\begin{tabular}{|c|c|c|}
\hline & $\begin{array}{l}\text { Malzemeler } \\
2 \text { yufka, } 200 \text { gr haşlanmış yeşil } \\
\text { mercimek } \\
20 \text { gr sadeyağ, } 100 \text { gr soğan } \\
2 \text { gr pul biber, kişniş, kimyon, } \\
5 \text { gr tuz } \\
30 \text { gr sadeyağ, yufkayı } \\
\text { yağlamak için }\end{array}$ & $\begin{array}{l}\text { Yapılış tekniği } \\
\text { Sade yağda soğan kavrulur. } \\
\text { Üzerine mercimek, tuz, pul } \\
\text { biber, kimyon, kişniş ilave } \\
\text { edilir. Yufkanın üzeri } \\
\text { sadeyağla yağlanır. Üzerine } \\
\text { diğer yufka serilir, yă } \\
\text { sürülür. Yufka } 8 \text { eşit parçaya } \\
\text { ayrılır. Her bir parçaya iç harc1 } \\
\text { konur ve kenarları kapatılarak } \\
\text { rulo şeklinde sarılır. Üzerine } \\
\text { yumurta sarısı sürülür. } \\
\text { Fırında pişirilir. }\end{array}$ \\
\hline
\end{tabular}

\section{Zerdeçallı Nohutlu Kapuska}

Kış menüsünde 1sıtıcı, sindirim çalıştırıcı bir yemek olarak başta Kaphalar olmak üzere pittalar içinde iyi bir tercihtir. Yemeğin içindeki zerdeçal sayesinde metabolizma hızında artış, içerdiği bitkisel protein kaynağı nohut sayesinde besin değerinde artış söz konusudur. Türk mutfağında daha çok etli pişen bu yemek ayurvedanın temelini oluşturan vejetaryen beslenmeye uygun olması açısından etsiz pişirilmiştir. Vejetaryen olmayanlar için istenilirse (kuzu veya keçi, tavuk) etiyle pişirilebilir.

\begin{tabular}{|l|l|l|}
\hline Malzemeler & $\begin{array}{l}\text { Yapılış tekniği } \\
400 \text { gr beyaz lahana, 200 gr } \\
\text { soğan } \\
100 \text { gr haşlanmış nohut } \\
\text { Sade yağda soğan } \\
\text { kavrulur. Rendelenmiş taze } \\
\text { zerdeçal ve tane kimyon } \\
\text { ilave edilir. Daha sonra } \\
\text { domates salçası ve lahana, } \\
\text { kalın bulgur üzerine ilave } \\
\text { edilip kavrulur. Daha } \\
\text { sonra sicak su ilave edilip } \\
30 \text { dk pişirilir. En son } \\
\text { nohut, pul biber ilave } \\
\text { edilir. }\end{array}$ \\
\hline
\end{tabular}

\section{Zerde}

Türk mutfağının bu geleneksel tatlısı kaphalar için çok uygundur. Kapha grubuna süt tüketimi önerilmediğinden sütlü bir tatlı yerine bu tatlının suyla yapılması ve içindeki zerdeçalın kaphayı azaltıcı ve dengeleyici etkisi olacaktır. Bu dosha grubuna baldan başka hiçbir tatlandırıcı önerilmediğinden bu tatlı bal ile yapılmıştır. Vata ve pitta doshaları içinde meyve şekeriyle tatlandırılması uygun olacaktır. 


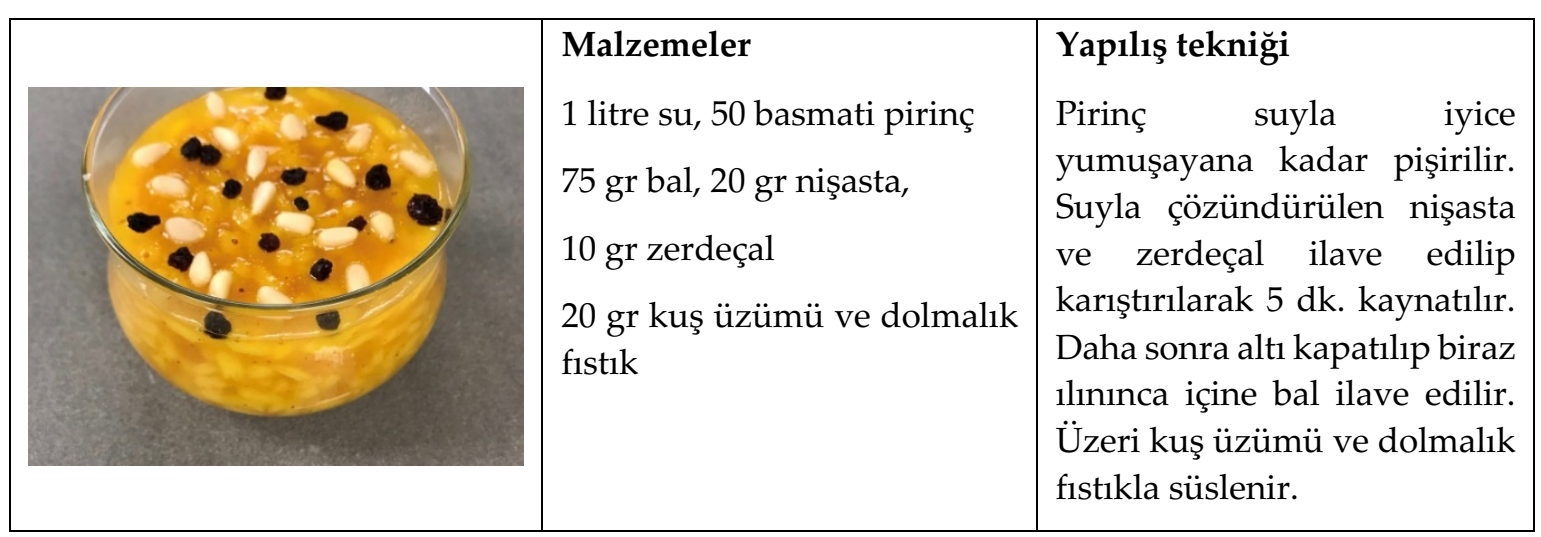

\section{SONUÇ VE ÖNERILER}

Hızlı ve hazır gıdalarla beslenmenin arttığı günümüz dünyasında çok zengin ve köklü bir geçmişe sahip olan Türk Mutfağı lezzeti, verimli toprakları olan bir coğrafyada olmasının sağladığı ürün ve buna bağlı olarak yiyecek-içecek çeşitliliği, yiyecekleri hazırlama ve saklama yöntemleri ile dünyanın önde gelen ve merak edilen mutfakları arasında bulunmaktadır (Solmaz ve Altınel, 2018). Ayurveda sağlık ve beslenme sistemine bakıldığında tavsiye edilen sebzelerin, meyvelerin, baharatların, yağlı tohumların birçoğunun Türk mutfağının kendi özgün yapısı içerisinde yüzyıllardır kullanılmakta olduğu görülmektedir. Ayurveda beslenme sisteminde alkole yer verilmemesi Türk yemek yapımında alkol kullanılmaması açısından benzelik göstermektedir (Bhattacharya, 2015). Bu çalışma neticesinde; Ayurveda merceğinden bakılarak, gerek Türk mutfak kültürüne ait malzemelerle, gerek Türk mutfağına ait geleneksel yemeklerin ayurvedaya uyarlanmasıyla, gerekse bu felsefenin doğduğu yer olan Hindistan'a özgü yiyeceklerin ayurvedik menüler hazırlayabilmek için Türk mutfağı ile buluşmasıyla; lezzetinden, görünümünden ödün verilmeksizin her üç doshaya göre ayurvedik menüler oluşturmanın mümkün olduğu görülmektedir. Özellikle Batıda çok ilgi gören ayurveda felsefesinin Türkiye'de de bilinir olmaya başladığı düşünüldügünde, belirli restoranlarda Vata, Pitta ve Kapha doshalarına uygun yiyecekiçecek seçenekleri olabilir. Ayurveda menü planlaması yapılan daha önceki çalışmalara bakıldığında sadece ayurveda beslenme sisteminden bahsedilip standart 2-3 tane ayurvedik yemek tarifi örneği verilmiş fakat Türk yemeklerine özgü uyarlama yapılan bir çalışma bulunmamıştır. Bu çalışmada ise bütün dosha gruplarına özel mevsimsel özel menü planlanıp, menü de bulunan yemekler tek tek uygulama yapılarak ayurvedik beslenme sistemine ve Türk yemek kültürüne uygun yemekler yapılmıştır. Bu açıdan bakıldığında bu çalışma alanında tek ve özgün bir çalışma niteliğine sahiptir. Bu çalışmada, hem Türk yemek yeme alışkanlıklarına uygun ayurvedik menüler planlanabileceği hem de bu planın günümüz menü sıralamasına uygun yapılabileceğini ortaya konmuş ayrıca bu çalışma çerçevesinde yeni, lezzetli ve ayurvedik menüler geliştirilebileceği görülmüştür. Örneğin, Türk mutfak kültüründe önemli bir öğün olan kahvaltı, her üç doshaya uygun bir şekilde ve aynı zamanda Türk kahvaltı alışkanlıklarını da dikkate alarak planlanıp restoran menülerinde tüketicilere alternatif olarak sunulabilir. Ayurveda ile ilgili yapılan çalışmalar incelendiğinde Türk mutfak kültürü ve beslenme alışkanlıklarını yansıtan yemekleri içermediği görülmektedir. Türk mutfak kültüründe var olan mevcut malzemelerle ayurvedik beslenmeye uygun tabaklar hazırlanabilmesi de restoranlara ekstra maliyet yansıtmaması yönüyle önemlidir. Türkiye'de bazı restoran menülerinde de ayurveda beslenmesinde önemli bir içecek olan 'Altın Süt'ün yer alması sağlıklı beslenmeye yönelik talebin artmasının bir göstergesi olduğu söylenebilir. Bununla birlikte hem sağlıklı beslenmek isteyenlerin hem de alternatif beslenme eğilimlerine yönelen kişilerin Hint kökenli ayurveda mutfağında yaygın olarak kullanılan sadeyağ ve zerdeçalın birleşimi olan zerdeçallı sadeyağın popüler kullanımı söz konusudur. Bu tarz beslenmeye duyulan ilginin ve talebin yiyecek-içecek sektörünce değerlendirilmesi bir ihtiyacın karşılanması noktasında önemlidir. Tüm bu açlardan bakıldığında hem ayurvedaya hem Türk beslenme özelliklerine uygun seçenekler 
sunması, fikirler vermesi ve bu konuda yapılacak olan başka çalışmalara öncülük etmesi yönüyle de dikkat çekicidir. Bu çalışmada bütün dosha grupları sadece sonbahar-kış menüsü hazırlanmıştır. Bundan sonra yapılacak diğer çalışmalarda bütün dosha grupları için ilkbahar-yaz yemek ve içecek menüsü oluşturulmasının hatta ayurveda yemek yeme sisteminin başka ülke mutfaklarına uyarlanarak menüler oluşturulmasının bu alanda pek çalışma olmadığından literatüre katkı sağlayacağı düşünülmektedir.

\section{KAYNAKÇA}

Ailawadi, P, (2018). Ayurvedic Cuisine, Journal of Business and Management Conference, 52-59

Aksoy, M., Örgün, E. ve Keskin, E., (2015). Ayurveda Beslenme sistemine Göre Menü Planlama, Eurasia International Tourism Congress: Current Issues, Trends, and Indicators.

Allmenginder, U., (2019). Ayurveda, Doğan Novus Yayınları, İstanbul.

Altınel, H., (2017). Menü Planlama ve Yönetimi, Detay Yayıncllık, Ankara.

Bhattacharya, B., (2015). Everday Ayurveda: Daily Habits That Can Change Your Life, Random House, India.

Büyüktuncer, Z. ve Yücecan, S., (2009). Türk Mutfağının Beslenme ve Sağlık Açısından Değerlendirilmesi, Beslenme ve Diyet Dergisi, 47(1): 93-100.

Chen, M. F. (2011). The Joint Moderating Effect of Health Consciousness and Healthy Lifestyle on Consumers' Willingness to Use Functional Foods in Taiwan, Appetite, 57(1), 253-262.

Çakıcı, A.C. Ve Yıldız, E., (2017). Restoran Müşterilerinin Sağlık Bilincinin Sağlıklı Yeme Davranışına Etkisi, Dergipark, Nevşehir Hacı Bektaş Veli Üniversitesi SBE Dergisi, 8(1): 1-22

Frawley, D. and Ranade, S., (2012). Ayurveda Nature's Medicine, Lotus Press, Germany.

Kraft, F.B. and Godell, P.W., (1993). Identifying the Health-Conscious Consumer, Marketing Health Service, 13(3): 18-25.

Jindabot, T. (2015). The Relationship of Thai Consumers' Health Consciousness and Perceived Value: Prince of Songkla University, Thailand, 1-10.

Jones, C. S. (2009). Taking Up Space? How Customers React to Health Information and Health Icons on Restaurant Menus, Journal of Food Service Business Research, 12(4), 344-363.

Lad,V., (2015). Ayurveda, Egan Yayıncılık, İstanbul.

Mukherjee, P.K. and Wahile, A., (2006). Integrated approaches towards drug development from Ayurveda and other Indian System of medicines, Journal of Ethnopharmacology,103(1): 25-35.

Pandey, M.M., Rastogi, S. and Rawat., A.K.S. (2013), Indian Traditional Ayurvedic Systems of Medicine and Nutritional Supplementation, Evidence-Based Complementary and Alternative Medicine, 2013(376327): 1-12

Sharma, H. and Clark, K., (1999). Çağdaş Ayurveda, Sistem Yayıncılık, İstanbul.

Saraç, E, (2002). Ayurveda'yla Sağlıklı Zayıflamanın Yolları, Doğan Egmont Yayıncılık, İstanbul.

Sarkar, P., Kumar, L., Dhumal, C. and Panigrahi, S., (2015). Traditional and Ayurvedic Foods of Indian Origin, Journal of Ethnic Foods, 2(3): 97-109.

Solmaz, Y. ve Dülger Altıner, D., (2018). Türk Mutfak Kültürü ve Beslenme Alışkanlıkları Üzerine Bir Değerlendirme, Safran Kültür ve Turizm Araştırmaları Dergisi, 1(3): 108-124

Sondhi, A., (2010). The Modern Ayurvedic Cook Book, Arsenal Pulp Press, Canada.

Svoboda, R.E., (2004). Ayurveda. The Ayurvedic Press, New Mexico. 
Şener, E., (2008). Ayurvedik Beslenme, Hasad yayıncllık, İstanbul.

Şinik, E., (2018). Genleriniz kaderiniz Değildir, Libros Yayıncılık, İstanbul.

Tokyürek, H., (2014). Eski Uygurcada Ayurveda Tıbbı ve Beş Unsur, İstanbul Üniversitesi Türkiyat Mecmuas, 1(24): 235-260.

WHO. (2010). Benchmarks for Training in Ayurveda.

Yıldırım, A. ve Şimşek, H, (2013). Sosyal bilimlerde nitel araştırma yöntemleri, Seçkin Yayıncılık, Ankara. 